\title{
Correlation Between Postpartum Anemia and the Increase of Baby's Weight in Ledug, Kembaran, Banyumas, Indonesia
}

\author{
Susilo Rini \\ Department of Midwifery \\ Harapan Bangsa University \\ Purwokerto, Indonesia \\ susilorini@uhb.ac.id
}

\author{
Feti Kumala Dewi \\ Department of Midwifery \\ Harapan Bangsa University \\ Purwokerto, Indonesia \\ vettykumala@gmail.com
}

\begin{abstract}
Background: Postpartum period is a critical period throughout a woman's life cycle. Many problems arise during the puerperium, one of them is anemia. In 2012, The data of Family Health Survey showed that the incidence of anemia in postpartum mothers reached $45.1 \%$. It had an impact on the supply of nutrients through breast milk which is very important for the growth and development of the baby, because breast milk is the main food for babies which is also affected by the nutritional status of the mother. This baby growth assessment can be seen from the increase in baby's weight which is updated regularly every month. Aim: To ensure that the baby's growth runs optimally. In addition, to know the other factors influencing the quality of postpartum breastfeeding that should be considered. Method: Design of this study was Cross Section, with a sample of 30 postpartum breastfeeding mothers and their babies. The sampling technique used was purposive sampling. Data was analyzed by Chi-Square test with a significance level of $95 \%$ (alpha 0.05 ).

Result: Most babies had normal body's weight, which was $84 \%$ and only 4 babies $(13 \%)$ experienced low weight gain. While postpartum mothers having a history of anemia as many as 7 respondents $(23 \%)$ of 30 postpartum breastfeeding mothers. The chi-square test results showed that the value of calculation was 25,000 with a value of table was 3.841 so that the calculation value $>\chi^{2}$ table $(25,000>3.841)$. It was strengthened by the value of $b$-value $<\alpha(0,0001<0,05)$. This means there is a relationship between the anemia of exclusively breastfeeding postpartum mothers and the increase in the baby's weight with the value of the correlation coefficient based on the table is 0.447 which means that the strength of the relationship between them is moderate.

Conclusion: There is a relationship between the postpartum anemia of mothers who are exclusively breastfeeding, with an increase in their baby's weight.
\end{abstract}

Keywords: postpartum, anemia, baby's weight

\section{INTRODUCTION}

The puerperium is a critical period for mothers, where the uterus condition start returning to their pre-pregnancy state. At this time the mother undergoes many physiological changes, but on the other hand the mother must not only focus on herself care, but also on the care of her baby including breastfeeding.

Breastfeeding is a scientific process. Nutritional intake in postpartum mothers greatly influences the quality of the milk produced. Lack of nutritional intake can cause anemia. The incidence of anemia in postpartum mothers will reduce milk production, both in quality and quantity.

The prevalence of anemia in postpartum mothers according to $\mathrm{WHO}$, amounted to $41.8 \%$ while in Indonesia the incidence of anemia was relatively high at $63.5 \%$. The result of Household Health Survey (SKRT) in 2012 stated that the prevalence of anemia in postpartum mothers reached 45.1\% (Ministry of Health Republic of Indonesia, 2013). The rate of anemia in Central Java in 2012 reached 57.1\%, while in Banyumas Regency especially Kembaran 2 Health Center in March 2019 postpartum mothers with Anemia were still quite high, reaching $60.57 \%$.

The occurrence of anemia in postpartum mothers not only affects the nutritional status of the mother herself but also the nutritional status of her, and it can be a contributing factor to the cases of stunting. However, research conducted by Setyani (2018) shows that there is no significant relationship between breastfeeding mothers with anemia and the nutritional status of infants. But, the amount of milk production depends on the amount of fat reserves during pregnancy. When doing breastfeeding, a mother produces around $800-1000 \mathrm{cc}$ of breast milk. Whereas the average volume of breast milk of poor nutritional status is only around 500-600 ml. If the nutritional status of the mother continuous, it may cause iron deficiency that can cause anemia and affect the amount of nutrients carried by the mother's blood cells to produce milk. This will have an impact on the low quality of breast milk produced so that 
it can disrupt the development and growth of the breastfed babies.

Based on the Nutrition report in the First 1000 Days State of the World's Mothers in 2012 stated that the incidence of stunting is influenced by conditions in 1000 days of life, starting from the fetus in the stomach or when a woman is pregnant until the child is 2 years old and this period is called the windows critical period, because during this period there is brain development or intelligence and rapid body growth (Imtihanatun, 2014).

The results of a preliminary study in Ledug Village found various problems that affected the high morbidity and mortality rates of mothers and babies during the puerperium. In 2017 exclusive breastfeeding coverage was only 68. During the period of January-April 2018 there were 3 Infant Mortality Rates. In addition to the high incidence of postpartum maternal anemia which reached to $60 \%$, the incidence of underweight babies was also found. Therefore, further research was needed with the aim of finding out the relationship between postpartum anemia and infant weight gain in the Ledug village in 2019.

\section{METHOD}

The research model used was Cross Sectional. The study population was all postpartum mothers in Ledug village with total population was 41 people and a total sample of 30 postpartum mothers having an exclusive breastfeeding. The sampling technique used was purposive sampling with the inclusion criteria of puerperal women who requested anemia which was approved and paid for exclusive breastfeeding. The instrument for measuring hemoglobin levels was the Cyanmethemoglobin method, while the instrument used to measure the babies' weight was age-appropriate scales.

The intervention procedures and data collection in this study included:

1. Choosing postpartum mothers who meet the inclusion criteria to be respondents, including ensuring anemia suffered by postpartum mothers.

2. Asking for their willingness to participate. For prospective respondents giving their approval, researchers asked their signature on the informed consent sheet.

\section{Examining the baby's weight.}

The data was analyzed by SPSS program and The analysis in this study was divided into 2 methods, they were univariate analysis using the frequency distribution to see the characteristics of respondents, and Chi Square with a significance level of $95 \%$ (alpha 0.05) to find out the relationship between anemia of breastfeeding mothers and breastfed babies' weight.

\section{RESULTS AND DISCUSSION}

Table 4.1 describes the data of babies weight increase in all of postpartum mothers with exclusively breastfeeding in the village of Ledug Kembaran Banyumas, Central Java in 2019.

Table 4.1 Frequency Distribution of babies weight Increase

\begin{tabular}{|c|c|r|}
\hline $\begin{array}{c}\text { Babies Weight } \\
\text { Increase }\end{array}$ & $\begin{array}{c}\text { Frequency } \\
\text { (f) }\end{array}$ & Percentage (\%) \\
\hline Normal & 26 & $84 \%$ \\
\hline Less Weigth & 4 & $13 \%$ \\
\hline Total & 30 & \\
\hline
\end{tabular}

Source: Primary Data (2019)

Table 4.2 Frequency Distribution of Postpartum Anemia History of Postpartum Breastfeeding Mothers in Ledug Village in 2019

\begin{tabular}{|c|c|c|}
\hline History of Anemia & $\begin{array}{c}\text { Frequency } \\
\text { (f) }\end{array}$ & $\begin{array}{c}\text { Percentage } \\
(\%)\end{array}$ \\
\hline Anemia & 7 & 23 \\
\hline $\begin{array}{c}\text { Not } \\
\text { anemia }\end{array}$ & 23 & 77 \\
\hline Total & 30 & \\
\hline
\end{tabular}

Source: Primary Data (2019)

Table 4.3 Relationship Between Postpartum Anemia in Breastfeeding Mothers and Infant Weight Gain in Ledug Kembaran Banyumas Indonesia

\begin{tabular}{|c|c|c|c|c|c|c|c|}
\hline \multirow{3}{*}{ Babies Weight } & \multicolumn{4}{|c|}{ Anemia } & \multirow{2}{*}{\multicolumn{2}{|c|}{ Total }} & \multirow{3}{*}{ p-value } \\
\hline & \multicolumn{2}{|c|}{$\begin{array}{c}\text { With } \\
\text { Anemia }\end{array}$} & \multicolumn{2}{|c|}{$\begin{array}{l}\text { Without } \\
\text { anemia }\end{array}$} & & & \\
\hline & $\mathrm{F}$ & $\%$ & $\mathrm{~F}$ & $\%$ & $\mathrm{f}$ & $\%$ & \\
\hline Normal & 3 & 42,9 & 23 & 100 & 26 & 87 & \multirow{2}{*}{0,0001} \\
\hline Less Weight & 4 & 57,1 & 0 & 0 & 4 & 13 & \\
\hline Total & 7 & 100 & 3 & 100 & 30 & 100 & \\
\hline
\end{tabular}

Source: Primary Data (2019) 
The Babies weight is the indicator that mostly used to assess the nutritional status of infants, which is the result of their nutritional intake fulfillment through exclusive breastfeeding. Soetjiningsih (2012) states that the increase in weight is calculated based on the table of weight increase, with an ideal benchmark for infant weight gain in the first year is 700-1000 grams / month in the first quarter. This research has proven the nutritional needs of infants were marked by an increase in normal weight according to the table, until the age of 6 months it is sufficient to be fulfilled with breastmilk. This is consistent with the results of research by Nila Kesuma (2015) which states that babies who are exclusively breastfed $80 \%$ have normal nutritional status. Based on table 4.2 it can be seen that postpartum mothers who have a history of anemia are 7 respondents $(23 \%)$. This is consistent with the 2012 SKRT data which states that the prevalence of puerperal women with anemia is around $45.1 \%$ of all pregnant women in Indonesia. This will affect the expenditure and quality of the milk produced. Anemia in the puerperium is a condition of maternal $\mathrm{Hb}$ levels below the normal limit during the puerperium (Prawirohardjo, 2014). The level of normal postpartum maternal $\mathrm{Hb}$ is $11 \mathrm{gr} \%$ (Manuaba, 2010). Postpartum mothers who have anemia have hemoglobin levels less than $11 \mathrm{gr} \%$ (Bothamley, 2011).

The incidence of anemia in postpartum mothers can be caused due to lack of nutritional intake. For women having anemia, it can cause risks for both mother and fetus. This is supported by the theory of Notobroto (2003) that poor nutrition can cause anemia and pregnant women with anemia can increase the risk of maternal death, prematurity, Low Birth Weight Babies (LBW) and infant mortality rates. The cause of indirect iron deficiency problem in anemic women is the lack of people's purchasing power to consume food sources of iron, especially with high biological readiness coupled with female blood loss through menstruation or during labor. Anemia is mostly caused by iron deficiency and most of the iron bound in hemoglobin functions specifically to transport oxygen for metabolic purposes in the tissues. Thus, if the mother is anemic, the metabolism in the tissue will be disrupted thereby reducing the quality of breast milk. This is consistent with the results of research conducted by Alvira, et al (2018) at Tegalrejo Public Health Center. The result showed that there was a significant relationship between the incidence of anemia with postpartum breast milk production. Based on table 4.3 it is known that postpartum anemia mothers who exclusively breastfed mostly had babies with underweight gain. In this research it was 4 respondents $(57.1 \%)$, while all mothers who did not have a history of anemia had babies with normal weight gain as many as 23 respondents $(100 \%)$. Chi-square test results showed that the calculated value was 25,000 with a value of table was 3.841 so that calculated value $>\chi 2$ tables $(25,000>3.841)$. The $p$ value based on the calculation above was 0.0001 with a significance level of $5 \%$ and the $\alpha$ value was 0.05 . Thus, it can be concluded that $\mathrm{p}$-value $<\alpha(0.0001<0.05)$ then Ho was rejected and Ha was accepted. This can be interpreted that there is a relationship between anemia of postpartum mothers who breastfeed exclusively and the weight gain of the babies. Anemia in postpartum mothers who breastfeed exclusively for 6 months can be interpreted as a condition where the level of hemoglobin (HB) in the mother's blood is lower than normal values through laboratory tests. The HB category is said to be normal if it is more than $12 \mathrm{mg} / \mathrm{dL}$ and it is said to be anemic if it is less than $12 \mathrm{mg} / \mathrm{dL}$ (Setiyani, 2013). The prevalence of anemia in breastfeeding mothers can be influenced by several things such as the nutrition intake of postpartum mothers, and noncompliance with taking blood booster tablets during pregnancy and post-partum. Moreover, the absence of government programs related to supplementation of blood booster tablets in the first 6 months of birth (breastfeeding) can also be a reinforcing factor of anemia in postpartum mothers. This condition greatly affects the nutritional status of infants, which is characterized by weight gain in infants.

The nutritional status of a baby is defined as the balance of nutrients needed by the body which is measured by using the body weight indicator per age (weight / age), which is then matched with the baby's weight gain table according to sex.

Breast milk is the main food for infants aged 0-6 months which becomes the basis of the increase of babies' weight because it is given without any supplementary food or drinks other than drugs. However, infants aged 0-6 months are prone to disease. The uncontrolled frequency and duration in breastfeeding will also have an impact on increasing morbidity in infants so that it also affects the nutritional status of infants.

In this study there were 7 babies with less weight gain in which 4 of them received exclusive breastfeeding from postpartum Anemia mothers. The results also showed that there was a relationship between anemia of postpartum mothers who breastfed exclusively and the weight gain of the breastfed babies. This study is in line with research conducted by Nadilla and Soimah (2018) at Tegalrejo Public Health Center in Yogyakarta which states that f3 out of 28 anemic postpartum mothers have good milk production, while the other 22 have less milk production.

Another study conducted by Setiyani, et al (2013) showed slightly different results namely that there was no relationship between the incidence of anemia in postpartum mothers and the nutritional status of infants aged 0-6 months. The absence of this relationship is due to the lowest hemoglobin measurement obtained was $8.6 \mathrm{mg} / \mathrm{dL}$ with an average of $11.75 \mathrm{mg} / \mathrm{dL}$, in which this number belonged to the category of mild anemia. Mild anemia in nursing mothers only affects the quality of breast milk. The condition of mild anemia has no visible symptoms but in the long term it will have an effect on severe anemia and will gradually reduce the nutritional status of the baby until the age of 2 years while the baby is still breastfed. 
Journal American Medical Association. 2009; 301 (16): 16911701.

be influenced by the environment around the house that is unclean and non-hygienic life. This can cause the babies frequently get sick although some mothers have the awareness to breastfeed on demand or routinely. This is reinforced by the results of research conducted in the Bontoala District of Makassar in 2007 which showed that infants aged 0-6 months with a bad environment who were breastfed exclusively from healthy mothers still suffered from malnutrition (Setiyani, et al, 2013).

\section{CONCLUSION}

There is a relationship between the incidence of anemia of postpartum mothers who breastfeed exclusively and the infant weight gain in Ledug Village, Kembaran District, Banyumas District.

Suggestion: Postpartum mothers should consume blood booster tablets during breastfeeding and receive nutritional care to make sure the nutrition intake in order to prevent anemia. Moreover, a good environment with PHBS is highly needed. Policy holders should make policies related to blood tablet consumption program during childbirth to overcome the incidence of anemia in breastfeeding.

\section{REFERENCES}

[1] Kementerian Kesehatan RI. Direktorat Jenderal Bina Gizi dan Kesehatan Ibu dan Anak. Petunjuk Surveilans Gizi. Jakarta. 2012.

[2] Ikatan Dokter Anak Indonesia. Nutrisi Pediatrik dan Penyakit Metabolik. Jilid I. Jakarta: Badan penerbid IDAI. 2011

[3] Riset Kesehatan Dasar.Jakarta : Badan Penelitian Kesehatan Kementrian Kesehatan RI.2010.

[4] Subramanian, S.V, K. Ackerson, leland ScD, Davey Smith George, MD, DSc, dkk. Association of Maternal Height With Child Mortality, Antropometric Failure, and Anemia in India.
[5] Shashi raj, Faridi MMA, Usha Rusia, dkk. A Prospective Study of Iron Status in Exclusively Breastfed Term Infants Up to 6 Month of Age. International Breastfeeding Journal 2008, 3:3.

[6] Setiyani, L. Hubungan Kejadian Anemia Pada Ibu Menyusui dengan Status Gizi Bayi Usia 0-6 Bulan. skripsi.Semarang :Badan Penerbit Universitas Diponegoro. 2013.

[7] Mahan, L.Kathleen and Stump, Sylvia Escott.. Krause's Food \& The Nutrition Care Process. Edisi 13. Philadelpia : WB Saunders Co. 2012.p 731- 738

[8] Ari Sulistyawati. 2009. Buku Ajar Asuhan Kebidanan Nifas. Jakarta:Andi offset

[9] Bahiyatun. 2009. Buku Ajar : Asuhan Kebidanan Nifas Normal. Jakarta

[10] Eny Ratna A, dkk. 2009. Asuhan Kebidanan Nifas, Jogjakarta:Mitra Cendikia Press

[11] Jannah, N. (2011). Asuhan Kebidanan Nifas. Yogyakarta:ArRuzz.

[12] Julianti, S.Kep, dkk .2014. Materi Pelatihan Postnatal Care. Based Practice. Yogyakarta: Deepublish

[13] Keluarga Berencana untuk Pendidikan Bidan. Jakarta : EGC.

[14] Kurniawati, T., Chabibah, U. (2014). Pelaksanaan Pendidikan Kesehatan Tentang Ambulasi Dini Ibu Post Partum. Jurnal Kebidanan dan Keperawatan Vol. 10 hal 54-63

[15] Lestari, EP. (2010). Hubungan Rawat Gabung Dengan Mobilisasi of Karang Kedawung, Sooko, Mojokerto, Nursing Journal Vol.1 Dini Pada Ibu Nifas Hari Pertama di BPS Endang Desa Banaran Number 2. Kabupaten Kandangan Kabupaten Kediri. Jurnal AKP No 2 Obstetri Fisiologi. Bagian Obstetri Gynekologi FK UGM.

[16] Rini,S dan Dewi, FK. 2016. Panduan Asuhan Nifas dan Evidence.Universitas Indonesia.

[17] Setiyani, L dan Kusumastuti, AC. 2013. Hubungan Kejadian Anemia pada Ibu Menyusui dengan Status Gizi Bayi Usia 0-6 Bulan. Journal

[18] Pujiastuti, Nurul. 2010. Correlation Between Breastfeeding Mother, Maternal Nutrition Status With Breastfeeding Adequacy In Posyandu 